\title{
REE Distribution Pattern in Plants and Soils from Pitinga Mine-Amazon, Brazil
}

\author{
Maria do Carmo Lima e Cunha ${ }^{1 *}$, Vitor Paulo Pereira ${ }^{1}$, Lauro V. Stoll Nardi ${ }^{1}$, Artur C. Bastos Neto ${ }^{1}$, \\ Luiz Alberto Vedana ${ }^{2}$, Milton L. L. Formoso ${ }^{1}$ \\ ${ }^{1}$ Centro de Estudos em Petrologia e Geoquímica, Instituto de Geociências, Universidade Federal do Rio Grande do Sul, \\ Porto Alegre, Brazil \\ ${ }^{2}$ Programa de Pós-Graduação em Geociências, Universidade Federal do Rio Grande do Sul, \\ Porto Alegre, Brazil \\ Email: ${ }^{*}$ maria.cunha@ufrgs.br
}

Received July 19, 2012; revised August 17, 2012; accepted September 14, 2012

\begin{abstract}
The rare earth element contents of plant specimens of the families Rhamnaceae, Ampelozizyphus amazonicus Ducke (local name: Saracura-Mirá) and of Pteridófitas from genus Gleichenia sp. e Adiantum sp. (ferns) were determined and compared to those of the soils, in the Pitinga Mine area, Amazon, Brazil. The Pitinga mine district has large tin reserves genetically related to two granite bodies, Agua Boa e Madeira, both intrusive in volcanic rocks included in the Iricoumé Group. This deposit contains, also, bodies of cryolite and rare metals, such as $\mathrm{Zr}, \mathrm{Nb}, \mathrm{Ta}, \mathrm{Y}$ and REE. The REE biogeochemical signatures, shown by the collected plants, reflect the patterns of the respective soils. The $\mathrm{Eu}$ and $\mathrm{Ce}$ anomalies shown by some plant samples are inherited from soils, as well. The higher contents of REE observed in fern samples confirm they are accumulators and reflect the abundance of REE in the soils of Pitinga Mine region. Additionally, that supports their potential use in geochemical exploration and bioremediation. The results of this study stress the importance of biogeochemical research integrated with geochemistry of soils, rocks and minerals.
\end{abstract}

Keywords: Biogeochemistry; Ree; Amazonian Environment

\section{Introduction}

Rare Earth Elements (REE) have a particular importance in geochemistry, for all have very similar chemical and physical properties $[1,2]$. In low-temperature geochemical systems the mobility of REE depends mainly on the solubility of residual minerals that concentrate REE and on the capacity of fluids to transport them. REE concentrations in natural waters are very low and depends on the complexes which are capable to be formed. Clay minerals can concentrate relatively high amounts of REE [3]. HREE and LREE are generally fractionated during weathering as demonstrated by Nesbit [4].

Under natural conditions, the absorption of REE by plants is very low. Plants show total concentrations of REE in leaf ashes, in the range from 1 to $45 \mathrm{ppm} \mathrm{[5]} \mathrm{al-}$ though, some species can accumulate up to $500 \mathrm{ppm}$. Such variations are explained by the abundance of REE in the soil or, by the specific capacity of absorption shown by some species [6]. The light and heavy REE can be fractionated by internal processes of the plants, as admitted by Ding et al. [7] and Lima e Cunha et al. [8].

The bioaccumulation processes of REE have, nowa-

"Corresponding author. days, an increasing importance in geochemistry and environmental sciences due to their wide use in non-nuclear industry and agriculture, which can result in environmental contamination [6]. As far as mineral exploration is concerned, some authors [9-11], have discussed the use of vegetation in the identification of anomalous concentrations of REE in subsurface deposits. An advantage of using phytogeochemistry instead of soil geochemistry for mineral exploration is that the roots of plants can absorb metals from several cubic meters of substratum, so that, they represent a large volume of sampled material.

Since the Cretaceous, the covertures of the Amazon region are being modified by weathering processes originating deep alteration profiles, derived from a variety of source rocks [12]. The current climate, humid tropical, causes intense soil leaching and significant losses of chemical elements. In this way, bioprospection programs in the Amazonian region have, in many cases, some advantages in relation to soil sampling, since the B horizon is frequently covered by thick layers of humus or lateritic crusts with up to $200 \mathrm{~m}$ of thickness.

This paper, which focuses on the analysis and inter- 
pretation of environmental behaviour of the REE, aims to compare the representativeness of the biogeochemical method in relation to soil geochemistry in the Pitinga Mine, consisting the data integration a pioneering initiative in this knowledge area.

\section{Geological Setting}

Located in the State of Amazonas, the Pitinga mine district has large tin reserves genetically related to two granite bodies, Agua Boa e Madeira, both intrusive in volcanic rocks included in the Iricoumé Group, the largest geologic unit in this area [13-15]. The mine, in addition to being one of the world's largest producers of tin, contains expressive deposits of cryolite and rare metals, such as $\mathrm{Zr}, \mathrm{Nb}$, Ta, Y and REE. There also some minerals rich in $\mathrm{Li}, \mathrm{Th}, \mathrm{Be}, \mathrm{Rb}$ and sulfides $[16,17]$.

The sampling of plants and soils was concentrated in the Madeira granite soils and in areas where the volcanic rocks of Iricoumé Group are predominant. The Madeira Granite is composed of by four facies: biotite granite, porphyritic hypersolvus granite, rapakivi granite and, the albite granite facies, which is subdivided in core and border sub-facies [18]. According to Costi [19], these facies show significant variations of $\sum$ REE contents, from 180 to $1100 \mathrm{ppm}$. The Madeira Granite tin deposit has 164 million tons of disseminated ore, at a grade of $0.17 \%$ of $\mathrm{Sn}$ (cassiterite), $0.20 \%$ of $\mathrm{Nb}_{2} \mathrm{O}_{5}$ and 0.024 of $\mathrm{Ta}_{2} \mathrm{O}_{5}$, both contained in pyrochlore and columbite. The disseminated ore contains $0.17 \%$ of REE, concentrated mostly in xenotime. The volcanic rocks which are pre- dominant in the region of Pitinga Mine consist of effusive and pyroclastic sequences with associated hypabyssal bodies [14,15] (Figure 1).

\section{Materials and Methods}

Eighteen pairs of soil-plant samples were collected in the vicinity of Pitinga mine, in areas of granitic substratum, more precisely in the Albite granite $(\mathrm{ABG})$ and Biotite Granite (BG) facies and, also, in areas dominated by the volcanic sequences of Iricoumé Group.

Plant specimens of the families Rhamnaceae, Ampelozizyphus amazonicus Ducke (local name: SaracuraMirá) and of Pteridófitas from genus Gleichenia sp. e Adiantum sp. (ferns) were chosen for sampling, for they show wide distribution in the studied area and are of easy recognition.

The samples of leaves were dried in an oven at $80^{\circ} \mathrm{C}$ and, then, subjected to calcination (ashing) under temperatures of $450^{\circ} \mathrm{C}-500^{\circ} \mathrm{C}$ for a period of 6 to $8 \mathrm{~h}$. The ashes $(0.25 \mathrm{~g})$ were digested with $\mathrm{HClO}_{4}-\mathrm{HNO}_{3}-\mathrm{HCl}-\mathrm{HF}$ and analyzed by ICP-MS at Act Labs (Canada). The obtained results are expressed as weight ash. The soil samples, about $50 \mathrm{~g}$ each, were collected at a depth of approximately $20 \mathrm{~cm}$, at the same point where the sample plants were obtained. Soil samples were dried in an oven at $80^{\circ} \mathrm{C}$, broken up in a porcelain grail and the sieved grain fraction under 250 mesh was used. The samples were analyzed in ActLabs (Canada) by INAA and ICP (4A-Exploration methods and 4B-Lithium Metaborate

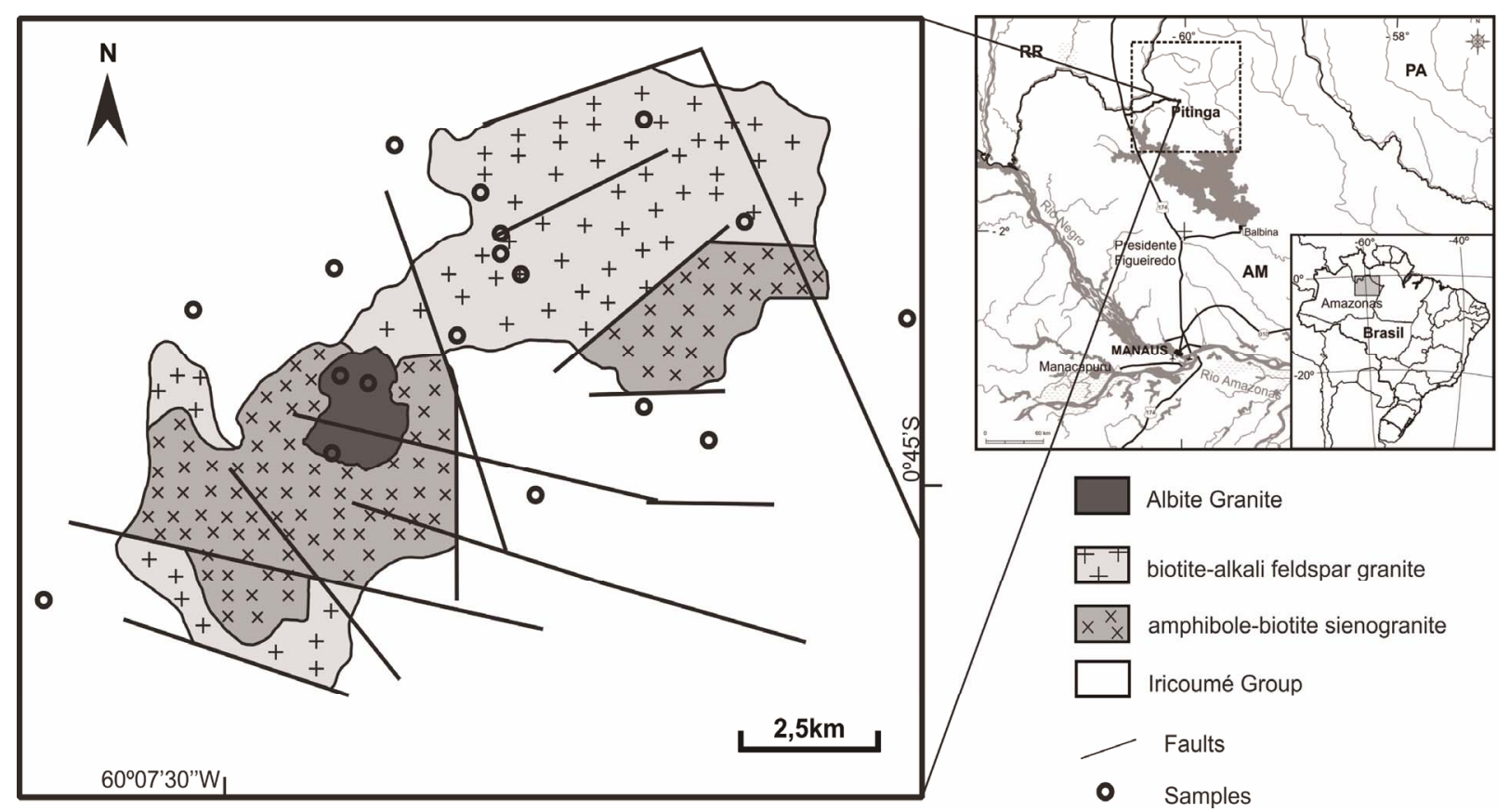

Figure 1. Geological map of Madeira Granite and associated volcanic rocks from Pitinga Mine with the sample location points. 
Fusion, respectively). The REE contents were normalized against the $\mathrm{C} 1$ chondrite values [20].

\section{Results}

The statistics representing the REE contents in plant (leaf-ashes of fern and Saracura-Mirá) and in soil samples collected in the Pitinga Mine area (Table 1), show that the sum of REE contents ( $\sum$ REE) is higher in plants than in soils. The exception is the Saracura-Mirá collected over the biotite-granite soils.

The fractionation of LREE (La-Eu) relative to the HREE (Gd-Lu) represented by LREE/HREE, is higher in plants than in soils, which demonstrates that LREE are more absorbed than the heavy ones by plants. Lima e Cunha et al. [8] observed the same behavior in previous studies in this same region. The plant/soil ratio of the $\sum \mathrm{REE}$ in areas where the substratum is volcanic is higher than in areas where it is granitic.

The contents of LREE, in areas with volcanic substratum, in most of the Saracura-Mirá ash samples, is about ten percent of soil contents and two percent for the HREE (Figure 2). The mean values (Table 1) for plants are strongly affected by two samples with very high and anomalous REE contents $\left(\mathrm{La}_{\mathrm{N}}\right.$ over 1000 , Figure 2). REE patterns of soils and plants in areas with volcanic substratum are approximately paralell, even in relation to those described by Horbe a Peixoto [12] for the lateritic covertures of volcanic areas in this region. The same is observed for the $\mathrm{Eu} / \mathrm{Eu}^{*}$ values, which are close to 0.31 and 0.38 for soils and plants, respectively. The contents of REE in ferns is very high in relation to soils (REE in plant $/$ REE in soil $=6$, Table 1) and, higher than those referred by Kabata-Pendias \& Pendias [5] for plants.

In the area dominated by the biotite granite the samples of Saracura-Mirá show REE contents lower than those of soils and, approximately parallel patterns (Figure 3). The $\mathrm{La}_{N} / \mathrm{Yb}_{\mathrm{N}}$ ratios in the plants is close to 7.55, whilst in the correspondent soils it is 1.77. The LREEsegment of normalized patterns (Figure 3) are similar in plants and soils and show, even, the Ce positive anomalies and the Eu negative ones. Two samples of fern colected in the biotite granite area, show the same property of concentrate LREE relative to the HREE (Table 1).

Table 1. Mean values of REE contents (ppm) in plant ashes and soils from Pitinga Mine area, Amazon.

\begin{tabular}{ccccccccccc}
\hline & ${ }^{*}$ Sara ${ }^{1}$ Volc & Soil Volc & ${ }^{* *}$ Sama Volc & Soil Volc & Sara ${ }^{2}$ Bg & Soil Bg & Sama Bg & Soil Bg & Sama ${ }^{3} \mathrm{ABg}$ & Soil ABg \\
\hline LREE & 195.66 & 28.2 & 2420.24 & 336.2 & 8.75 & 134.2 & 53.12 & 20.30 & 996.35 & 366.20 \\
HREE & 11.40 & 3.13 & 920.40 & 251.22 & 1.00 & 38.77 & 2.09 & 4.15 & 148.00 & 220.57 \\
LREE & 206.06 & 31.33 & 3340.64 & 587.42 & 9.75 & 172.97 & 55.21 & 24.45 & 1144.37 & 586.77 \\
LREE/HREE & 17.07 & 9.009 & 2.62 & 1.33 & 8.68 & 3.46 & 25.41 & 4.89 & 6.73 & 1.66 \\
La $_{\mathrm{N}}$ & 195.53 & 43.3 & 357.00 & 83.10 & 2.26 & 30.10 & 70.88 & 32.10 & 994.66 & 28.70 \\
\hline
\end{tabular}

"Saracura-Mirá; ${ }^{* *}$ Fern; ${ }^{1}$ Volcanic Substratum; ${ }^{2}$ Biotite Granite; ${ }^{3}$ Albite Granite.

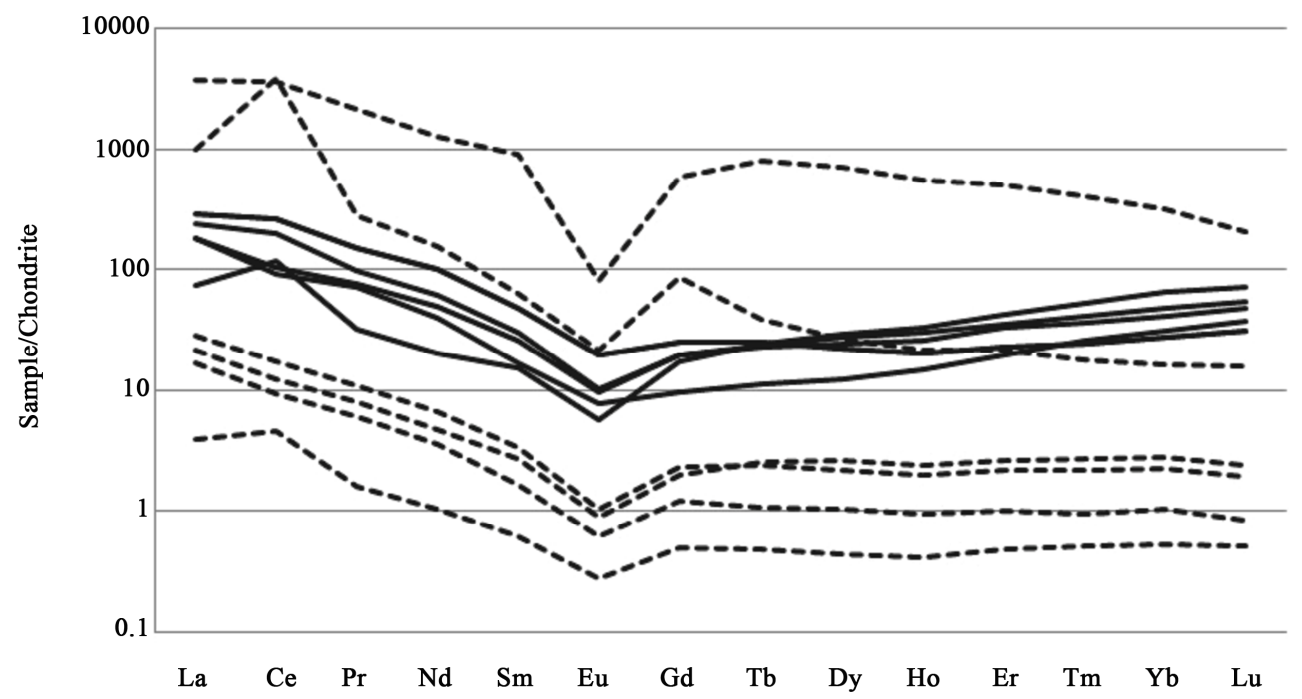

Figure 2. Biogeochemical signature of plants (Saracura-Mirá) and soils in areas of volcanic substratum from Pitinga Mine area. Full lines = soil; dashed lines $=$ plant. 


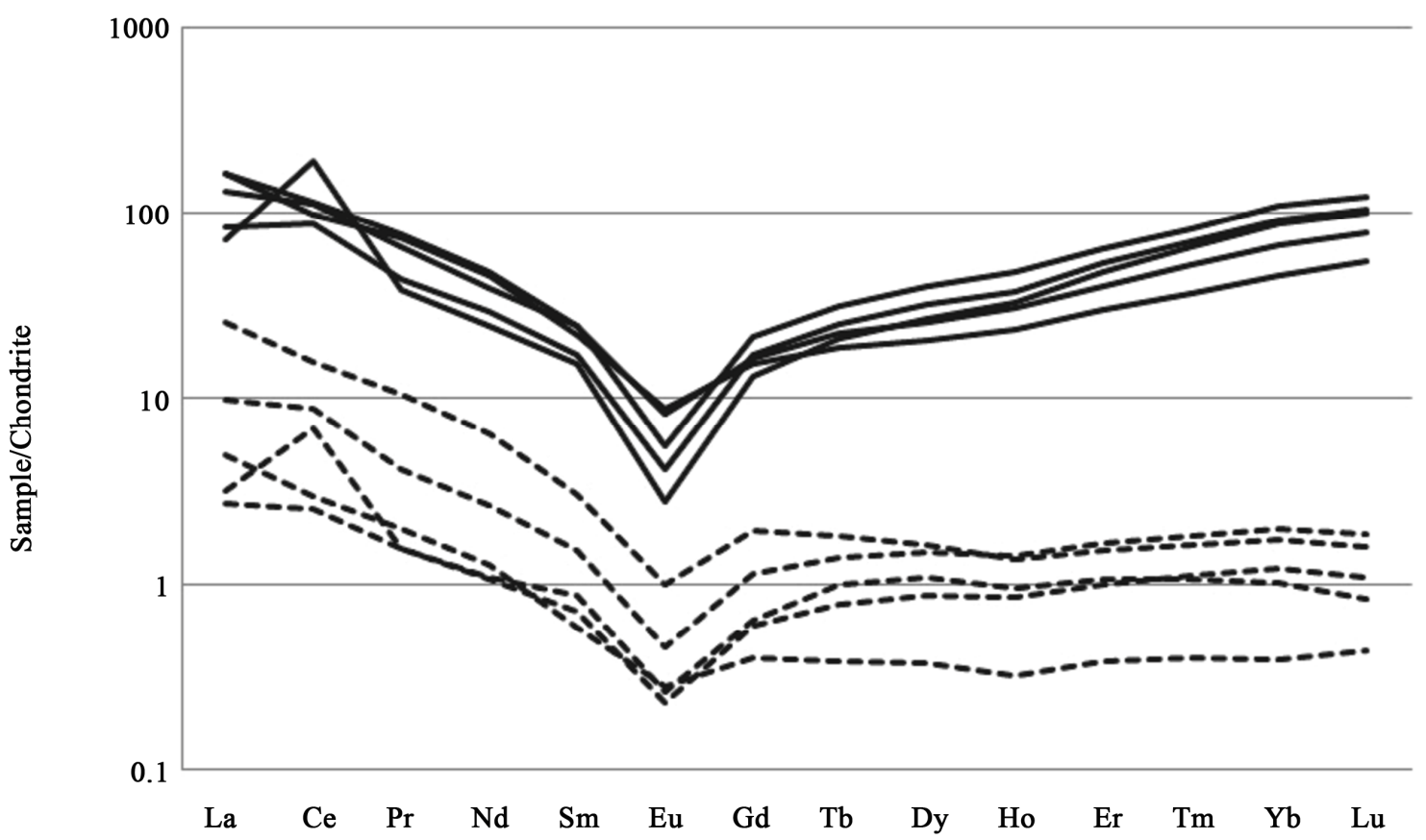

Figure 3. REE-chondrite normalised patterns in soils (full line) and in plants (Saracura-Mirá) in the biotite granite area.

The behavior of REE in soils and plants (ferns) from the albite granite area, where the mineralization is situated, is different from the previous areas with volcanic and biotite granite substrates. The soils are enriched in HREE and, ferns show concentration ten times higher than the correspondent soils for LREE. Additionally, soils and plants show strong negative Eu anomalies. The albite granites when compared to volcanic and biotite granites, show the same features, HREE enrichment and deeper negative $\mathrm{Eu}$ anomalies [21]. Differently, also, from the rocks, the soils and ferns in the albite granite area show distinct positive Ce anomalies (Figure 4).

\section{Discussion}

Volcanic and granitic rocks from Pitinga Mine area show REE patterns of some samples with M-type tetrad effect $[18,19,21]$, which are more noticeable in the third and fourth segments. Soils and plants, in some cases, keep the same features, even though, not so clear as in rock patterns. The tetrad effect in soils and plants from Pitinga Mine area are also suggested by high $\mathrm{Sm}_{\mathrm{N}} / \mathrm{Nd}_{\mathrm{N}}$ ratios and small positive $\mathrm{Gd}$ anomalies. The $\mathrm{Gd}$ positive anomalies have been referred by Ding et al. [6] and Xu et al. [22] in plant samples from elsewhere. Lima e Cunha et al. [23] registered these kind of anomalies in plant samples collected from soils over syenitic rocks in southernmost Brazil and concluded that, the Gd positive anomalies reflect the presence of M-type tetrad effect.

LREE are more absorbed than the HREE by plants from granitic and volcanic soils of Pitinga Mine area.
The presence of abundant zircon among the detrital phases of soils from the Pitinga Mine area, particularly, over the granitic rocks [12], explains why the HREE show low availability for plants. Zircon is a very resistant mineral to weathering and, a powerful concentrator of HREE. The ratio HREE in zircon/HREE in granitic magmas is close to unity for La and higher than 300 for $\mathrm{Lu}$ [21]. According to Tyler [24] the HREE in soil solutions, in general, come mostly from the dissolution of xenotime, which is a widespread phase in the mineralized albite granites from the Pitinga Mine area [25].

Volcanic and granitic rocks in the Pitinga Mine region show similar REE patterns with $\mathrm{La}_{\mathrm{N}} \sim 250, \mathrm{Lu}_{\mathrm{N}} \sim 25$ and slight negative Eu anomalies [14]. The soils which cover both rock types are strongly depleted in LREE in relation to rocks. The mean value of the ratio REE content in plant/REE content in soil in the granitic areas is lower than in the volcanic ones, 2.0 and 6.0 respectively. Such behavior can be explained, at least in part, by the finer grain size of volcanic soils, which would make the REE bearing phases more soluble and, consequently, more available for vegetal absorption [26]. Additionally, the REE in granitic rocks are mostly in accessory phases, such as, zircon, titanite, allanite and apatite [27], which are resistant to weathering and, therefore, would cause a decrease in the availability of REE for plants from granitic soils. The REE contents of Saracura-Mirá (Figures 2 and 3) is six times lower than that of the respective soil, which corroborates the assumption of Tyler [24], who affirms that the transfer from soil to plant is usually low and generally unrelated to their total concentrations in the soil. 


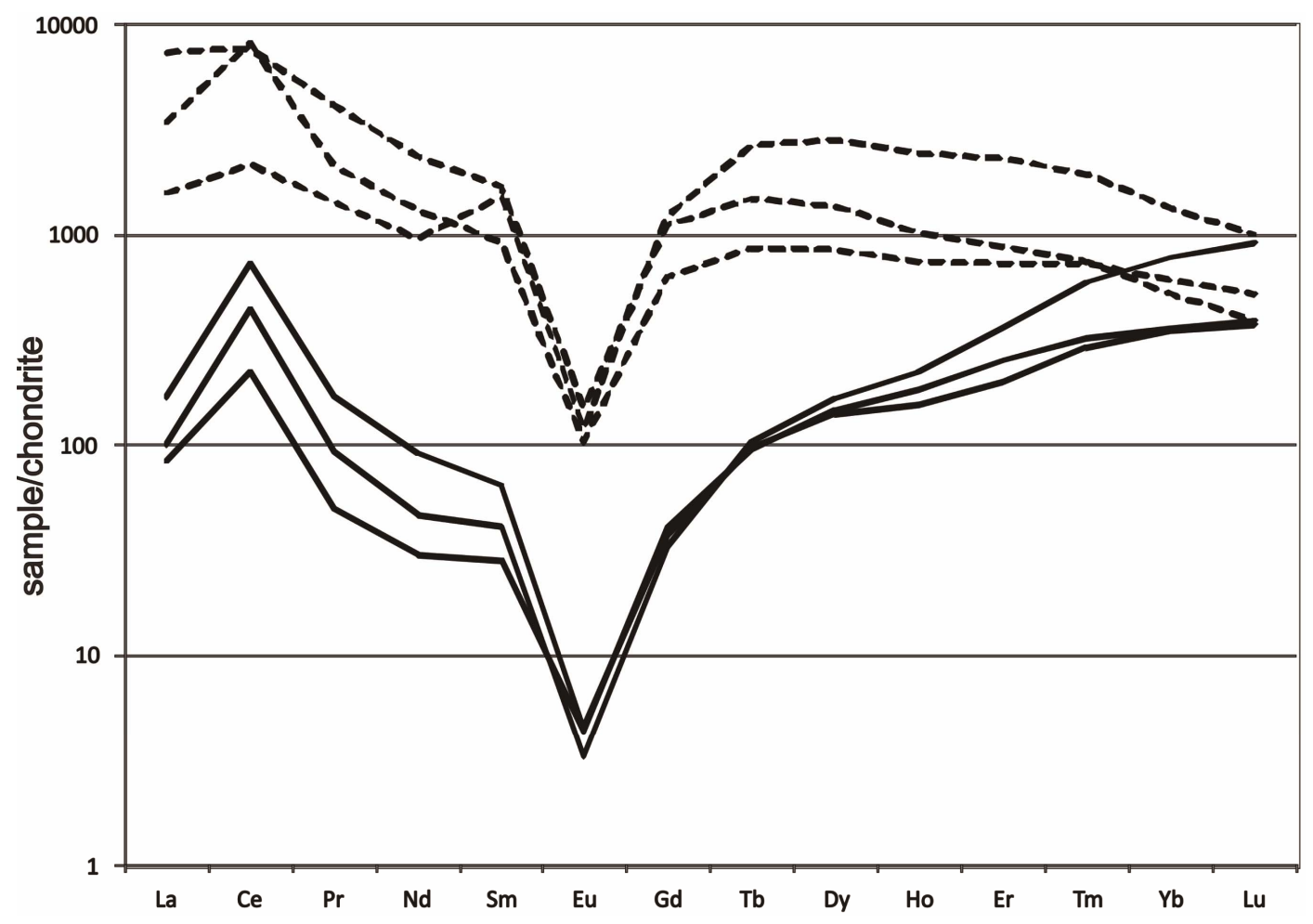

Figure 4. REE-chondrite normalised patterns of plants (fern) and soils in the albite granite area. Dashed lines = plants, full line $=$ soils.

On the other hand, the REE contents of fern samples (Figure 4) are higher than those of the respective soils, which is in good agreement with several authors that consider the pteridophytes effective accumulators of REE [28,29]. Tyler \& Olsson [29] affirmed that the capability, of many types of fern, for accumulate REE, is probably explained by particular absorption or solubilization processes developed by these plants. Ozaki et al. [30] suggested that the REE can have some positive role in the evolution of pteridophytes, as, for instance, to contribute for their adaptation to environmental changes.

The negative Eu anomalies shown by plants are a reproduction of soil and rock patterns (Figures 3 and 4), whilst, the positive $\mathrm{Ce}$ anomalies can be related to alteration processes related to soil formation.

\section{Conclusions}

Based upon the results obtained in this study and, with support on the research of other authors we conclude:

1) The biogeochemical signatures shown by the plants collected in the Pitinga Mine area, reflect the patterns of the respective soils;

2) The high concentrations of REE observed in the ferns (pteridophytes) are related to their high capacity of accumulate them and, to the high contents in the soils of the studied area;

3) The negative Eu anomalies in the studied plants show that they can indicate the geochemical features of rocks and soils; whilst, the positive $\mathrm{Ce}$ anomalies indicates the action of secondary processes in soils from the mineralized granites;

4) The relatively high contents of REE in ferns, make them accumulator species with potential use in geochemical exploration and bioremediation;

5) The results obtained in this study have stimulated the continuity of biogeochemical research integrated with geochemistry of rocks, soils and minerals.

\section{REFERENCES}

[1] P. Henderson, "Rare Earth Elements Geochemistry," Developments in Geochemistry, Elsevier, Amsterdam, 1984.

[2] H. R. Rollinson, "Using Geochemical Data: Evaluation, Presentation, Interpretation," John Wiley \& Sons, Hoboken, 1993.

[3] D. G. Brookins, "Aqueous Geochemistry of Rare Earth Elements," In: B. R. Lipin and G. A. McKay, Eds., Geochemistry and Mineralogy of Rare Earth Elements, Review in Mineralogy, 1989, pp. 201-225.

[4] H. W. Nesbitt, "Mobility and Fracctionation of Rare Earth Elements during the Weathering of a Granodiarite," $\mathrm{Na}$ ture, Vol. 279, No. 5710, 1979, pp. 206-210. doi: $10.1038 / 279206 \mathrm{a} 0$

[5] A. Kabata-Pendias and H. Pendias, "Trace Elements in 
Soils and Plants," CRC Press, Boca Raton, 2000. doi:10.1201/9781420039900

[6] S. M. Ding, T. Liang, C. S. Zhang, J. C. Yan and Z. Zhang, "Accumulation and Fractionation of Rare Earth Elements (REEs) in Wheat: Controlled by Phosphate Precipitation, Cell Wall Absorption and Solution Complexation," The Journal of Experimental Botany, Vol. 56, No. 420, 2005, pp. 2765-2775. doi:10.1093/jxb/eri270

[7] S. M. Ding, T. Liang, C. S. Zhang, Z. C. Huang, Y. N. Xie and T. B. Chen, "Fractionation Mechanisms of Rare Earth Elements (REEs) in Hydroponic Wheat: An Application for Metal Accumulation by Plants," Environmental Science Technology, Vol. 40, No. 8, 2006, pp. 2696-2691.

[8] M. C. Lima e Cunha, V. P. Pereira, A. C. Bastos Neto, L. V. S. Nardi, M. L. L. Formoso and E. Menegotto, "Biogeoquímica dos Elementos Terras Raras Na Província Estanífera De Pitinga (AM)," Revista Brasileira de Geociências, Vol. 39, No. 3, 2009, pp. 560-566.

[9] W. O. Robinson, H. Bastron and K. J. Murata, "Biogeochemistry of the Rare Earth Elements with Particular Reference to Hickory Trees," Geochimica and Cosmochimica Acta, Vol. 14, No. 1-2, 1958, pp. 55-67. doi:10.1016/0016-7037(58)90093-0

[10] C. E. Dunn and E. Hoffman, "Multi-Element Study of Vegetation from a Zone of Rare-Earth Rich Allanite and Apatite in Northern Saskatchewan, Canada," Applied Geochemistry, Vol. 1, No. 3, 1986, pp. 375-381. doi:10.1016/0883-2927(86)90022-3

[11] G. M. Pulz, E. S. Barboza, M. C. Lima e Cunha, C. J. Fernandes, F. E. Pinho, A. P. Quadros and M. Sobral, "Estudo Comparativo Dos Elementos Terras Raras E Ouro Na Prospecção Litogeoquímica, Geoquímica do Solo e Biogeoquímica Na Área do Depósito Pau-A-Pique, Grupo Aguapeí, Oeste de Mato Grosso," Anais Congresso de Geoquímica dos Países de Língua Portuguesa, 5 E Congresso Brasileiro de Geoquímica 7, Porto Seguro, 1999, Vol. 1, pp. 635-637.

[12] A. M. C. Horbe and S. F. Peixoto, "Geochemistry of Pitinga Bauxite Deposit-Amazonian Region-Brazil," In: R. W. Fitzpatrick and P Shand, Eds., Regolith-Consolidation and Dispersion of Ideas, Proceedings of the CRC Leme Regolith Symposium, Hahndorf, 2006, pp. 144-146.

[13] W. K. Daoud, "Granitos Estaniferos de Pitinga, Amazonas: Contexto Geológico e Depósitos Minerais Associados," Ph.D. Thesis, Dissertação de Mestrado, Universidade de Brasília, Brasília, 1988.

[14] J. M. T. M. Ferron, A. C. Bastos Neto, E. F. Lima, L. V. S. Nardi, H. T. Costi, R. Pierosan and M. Prado, "Petrology, Geochemistry and Geochronology of Paleoproterozoic Volcanic and Granitic Rocks (1.89 to $1.88 \mathrm{Ga})$ of the Pitinga Province, Amazonian Craton, Brazil," Journal of South America Earth Science, Vol. 53, No. 8, 2010, pp. 946-979.

[15] R. Pierosan, E. F. Lima, L. V. S. Nardi, C. P. Campos, A. C. Bastos Neto, K. Jarvis, J. M. Ferron and M. Prado, "Geochemistry of Palaeoproterozoic Volcanic Rocks of the Iricoumé Group, Pitinga Mining District, Amazonian craton, Brazil," International Geology Review, Vol. 53, No. 8, 2011, pp. 946-979.

doi: $10.1080 / 00206810903391542$
[16] R. Dall'Agnol, J. S. Bettencourt, N. F. Botelho and E. L. Klein, "Tin, Gold and Granitoids in Brazil," In: P. Bhattacharya and A. H. Welch, Eds., The 31st International Geology Congress, Rio de Janeiro, 2000, p. G6.

[17] R. M. K. Borges, R. Dall'Agnol and H. T. Costi, "Geologia, Petrografa e Química Mineral das Micas dos Greisens Estaníferos Associados ao Pluton Água Boa, Pitinga (AM)," Revista Brasileira de Geociências, Vol. 33, No. 1, 2003, pp. 51-62.

[18] A. Bastos Neto, V. P. Pereira, L. H. Ronchi, E. F. Lima and J. C. Frantz, "The World-Class Sn, Nb, Ta, (Y, REE, Li) Deposit and the Massive Cryolite Associated with the Albite-Enriched Fácies of the Madeira A-Type Granite, Pitinga Mining District, Amazonas State Brazil," The Canadian Mineralogist, Vol. 47, No. 6, 2009, pp. 1329-1357. doi:10.3749/canmin.47.6.1329

[19] H. T. Costi, "Petrologia de Granitos Alcalinos com alto Flúor Mineralizados em Metais Raros: O exemplo do Albita Granito da Mina Pitinga, Amazonas, Brasil," Doctoral Thesis, Federal University of Pará, Belém, 2000.

[20] N. M. Evensen, P. J. Hamilton and R. K. O'nions, "Rare Earth Abundances in Chondritic Meteorites," Geochimica and Cosmochimica Acta, Vol. 42, No. 8, 1978, pp. 1199 1212. doi:10.1016/0016-7037(78)90114-X

[21] L. V. S. Nardi, M. L. L. Formoso, K. Jarvis, L. Oliveira and A. C. Bastos Neto, "Geochemistry of Zircons in the Magmatic-Hydrothermal F-Rich system of Sn-Nb-Cryolite Mineralized Granites from the Pitinga Mine Region, Amazonia, Brazil," Journal of South America Earth Science, Vol. 33, No. 1, 2012, pp. 34-42. doi:10.1016/j.jsames.2011.07.004

[22] X. Xu, W. Zhu, Z. Y. Wang and G. J. Witkamp, “Accumulation of Rare Earth Elements in Maize Plants (Zea mays L.) after Application of Mixtures of Rare Earth Elements and Lanthanum," Plant and Soil, Vol. 252, No. 2, 2003, pp. 267-277. doi:10.1023/A:1024715523670

[23] M. C. Lima e Cunha, L. V. S Nardi and M. L. L Formoso, "Absorção e Fracionamento dos Elementos Terras Raras Por Vegetais: Estudo Comparativo Em Plantas Ocorrentes Em Diferentes Contextos Geológicos," Geologia USP, Série Cientifica, São Paulo, Vol. 10, No. 1, 2010, pp. 53-59.

[24] G. Tyler, "Rare Earth Elements in Soil and Plant Systems-A Review," Plant and Soil, Vol. 267, No. 1-2, 2004, pp. 191-206. doi:10.1007/s11104-005-4888-2

[25] A. C. Pires, "Minerais de Y e ETR (Xenotina, Gagarinita, Fluocerita e Waimirita) da Jazida Pitinga (Amazonas): cristaloquÍmica e Potencial Para Exploração," Doctoral thesis, Federal University of Rio Grande do Sul, Porto Alegre, 2010.

[26] L. A. Kovalevsky, "Biogeochemical Exploration for Mineral Deposits," NVU Science Press, Utrecht, 1987.

[27] L. P. Gromet and L. T. Silver, "Rare Earth Element Distribution among Minerals in a Granodiorite and Their Petrogenetic Implications," Geochimica and Cosmochimica Acta, Vol. 47, No. 5, 1983, pp. 925-939. doi:10.1016/0016-7037(83)90158-8

[28] Z. Y. Zhang, Y .Q. Wang, F. L. Li, H. Q. Xiao and Z. F. 
Chai, "Distribution Characteristics of Rare Earth Elements in Plants from a Rare Earth Ore Area," Journal of Radio Analytical and Nuclear Chemistry, Vol. 252, No. 3, 2002, pp. 461-465. doi:10.1023/A:1015834232718

[29] G. Tyler and T. Olsson, "Rare Earth Elements in ForestFloor Herbs as Related to Soil Conditions and Mineral
Nutrition," Biological Trace Element Research, Vol. 106, No. 2, 2005, pp. 177-191. doi:10.1385/BTER:106:2:177

[30] T. Ozaki, S. Enomoto, Y. Minai, S. Ambe and Y. Makide, "A Survey of Trace Elements in Pteridophytes," Biological Trace Element Research, Vol. 74, No. 3, 2000, pp. 261-273. doi:10.1385/BTER:74:3:259 